\title{
CAN THE AMERICAN ALLIANCE STOP COLLUDING IN GENOCIDE?
}

\section{Winton Higgins}

\begin{abstract}
Be careful. Legal at State was worried about this yesterday-Genocide finding could commit [the US government] to actually "do something"-Office of the US Secretary of Defence, secret discussion paper on the Rwandan genocide, 1994.
\end{abstract}

After 9/11, President Bush asked, "Why do they hate us?" From Iran (1953) to Iraq (2003), the better question would be, "Why would they not?"-Chalmers Johnson, 2010.

The concept of genocide, and outspoken abhorrence for what it stands for, have arisen over the last hundred years on the back of Western sensibilities and legal initiatives. Yet since the end of World War Two, Western countries have typically failed to take action against actual or impending genocides, in spite of the growth of explicit legal and moral obligations to do so. Some Western countries have even avoided denouncing genocidal regimes, and failed to withdraw their economic and diplomatic privileges from them. In some cases Western countries have colluded with these regimes in ways that go beyond bystanderism, even if bystanderism remains the most ubiquitous and effective form of collusion in virtually all historical genocides.

In this essay I probe this gap between pious recoil from genocide in the abstract on the one hand, and passive and active practical collusion in genocide on the other. I will extend the concept of active collusion to include self-interested (overt and covert) overseas incursions, ones that sow the seeds of genocide by unleashing mayhem on a grand scale, and subvert the long-term project of creating an international rule of law, of which the prevention of genocide forms an integral part. I look at the provenance of the contradiction between pious recoil and practical collusion, and at the challenge of closing the gap between sanctimonious self-preening and effective responses to genocide. Genocidaires commonly commit cognate crimes, such as starting wars, and crimes against humanity like routinised torture. I will treat these crimes 
as contextually significant in this analysis, as they take their place in the currently intense assault on the international rule of law as a whole.

Few Western countries enjoy the military and economic heft to unilaterally tackle genocidaires in distant lands. Thus, the main moral responsibility for Western failure to do so falls on the American alliance, which does possess ample capability, and claims a leadership role in the Western world (even though the alliance from time to time also includes non-Western countries). Membership of what I call "the American alliance” refers to substantial military or diplomatic co-ordination with the US, whether under the auspices of formal alliances such as NATO and ANZUS ${ }^{1}$; ongoing intimate military, intelligence and economic ties, such as those that bind Saudi Arabia, the Persian Gulf emirates, and Pakistan to the US; or ad hoc co-belligerencies such as the US, British and Australian invasion of Iraq in 2003.

The core members of the alliance, however, are the US, Britain and Australia-the latter two having played follow-my-leader in virtually all matters of diplomatic and military significance that relate to creating the preconditions for genocide, and subsequent inertia towards it. The focus of this inquiry falls on America itself, which sets the agenda for the alliance that bears its name. This focus in no way exonerates the other members of the alliance for their collusion in "the crime of crimes."

To ensure coherence and keep the essay within reasonable limits, I take this investigation through three stages, each represented by a major analyst. In the first stage, Samantha Power's monumental "A Problem from Hell”: America and the Age of Genocide accounts for the manoeuvres whereby American decision-makers have almost always evaded their moral and treaty responsibilities to confront genocide. ${ }^{2}$ (Power's analysis has added force given that she was the US ambassador to the UN between 2013 and 2017.)

As a prelude to the second and third stages, I briefly introduce Steven Pinker's hypothesis that links the suppression of violence (including genocide) to the consolidation of democratic governance. ${ }^{3}$ Since the American alliance has convincingly bucked this trend to suppress violence, I ask whether its democratic pretensions are now just as hollow as its commitment to "prevent and punish" the crime of genocide under the terms of the 1948 Convention on the Prevention and Punishment of the Crime of Genocide ("the Genocide Convention”), which the US and all its allies have either ratified or acceded to. Thus,

1 North Atlantic Treaty Organisation; Australia, New Zealand, United States Security Treaty.

2 Samantha Power, "A Problem from Hell”: America and the Age of Genocide (New York: Basic Books, 2007).

3 Steven Pinker, The Better Angels of our Nature: The Decline of Violence in History and Its Causes (London: Allen Lane, 2011), 194. 
in the second stage of the investigation, I place these sins of omission in the wider context of America's robust real-world foreign relations, and the nature of its domestic polity today. Our preliminary guide here is the late Chalmers Johnson in his so-called "blowback trilogy" and its sequel. ${ }^{4}$

In the third stage, I invoke Colin Crouch's "post-democracy” thesis. It highlights currently profound but less obvious democratic deficits in the core members of the American alliance-deficits that obstruct the emergence of a political will to meet moral and legal obligations in the face of today's genocidal threats. ${ }^{5}$

\section{The US and genocide since World War Two}

During the years from 1941 to 1949, the US proved itself on the world stage, not just as a military leader in the struggle against tyranny, but also as a moral and jurisprudential pioneer of a new international order based on the rule of law-one with the criminalising of aggressive war, foreshadowed in the 1941 Atlantic Charter, as its centrepiece. ${ }^{6}$ These years saw the development (in the Pentagon, under the auspices of the US Department of War) of the jurisprudence that underpinned the Nuremberg trials of 1945-1949 - themselves American initiatives that essentially created modern international criminal law. ${ }^{7}$

Raphael Lemkin coined the word "genocide" as a refugee in the US in 1944. It gained its first official airing in the indictment of October 1945 that triggered the first Nuremberg trial of Nazi leaders, which began in the following month under international auspices. This trial established the crime of aggressive war and crimes against humanity in international law. It set a precedent that stripped state perpetrators and their underlings of the automatic impunity that the institution of national sovereignty had previously afforded them. The erstwhile "prophets unarmed" of human rights now held a potential weapon in their hands: offences against these rights were now justiciable

4 Chalmers Johnson, Blowback: The Costs and Consequences of American Empire, 2nd ed. (New York: Holt Paperbacks, 2004); Chalmers Johnson, The Sorrows of Empire: Militarism, Secrecy, and the End of the Republic (New York: Metropolitan Books, 2004); Chalmers Johnson, Nemesis: The Last Days of the American Republic (New York: Metropolitan Books, 2007); Chalmers Johnson, Dismantling the Empire: America's Last Best Hope (New York: Metropolitan Books, 2010).

5 Colin Crouch, Post-Democracy (Cambridge: Polity, 2004).

6 In paragraph eight of the charter, President Franklin Roosevelt and Prime Minister Winston Churchill declared that "all nations of the world . . . must come to the abandonment of the use of force." See Philippe Sands, Lawless World: Making and Breaking Global Rules (London: Penguin, 2006), 8-9. As he points out, the charter inspired the emergence of the nascent "united nations" on the Allied side during the war.

7 Telford Taylor, The Anatomy of the Nuremberg Trials (London: Bloomsbury, 1993), 21-42; Colin Tatz and Winton Higgins, The Magnitude of Genocide (Santa Barbara: Praeger, 2016), 174-77. 
and punishable. Twelve follow-on trials in Nuremberg, under purely American auspices, cemented the precedent. The UN General Assembly affirmed the status of the "Nuremberg principles" in 1947 as part of international law, and tasked the International Law Commission to formulate them in precise legal terms, which the latter published in $1950 .^{8}$

In May 1945, the US hosted the founding congress of the United Nations in San Francisco. Its charter's opening words declare the intention to save future generations from "the scourge of war" and to defend human rights. In the years immediately following, Eleanor Roosevelt chaired the fledgling UN Human Rights Commission and presided over the drafting of the Universal Declaration of Human Rights (UDHR) on the shores of Lake Success, New York..$^{9}$ It was duly adopted by the UN in 1948, together with the Genocide Convention, the first signatory of which was the US itself. The UDHR created rights that inhered in all human beings without exception, not as "gifts" that could be withdrawn by political authorities. ${ }^{10}$

Taken together, these American-led innovations laid the basis for an international rule of law that set its face against warmongering, genocide, and a host of other human rights abuses. For America itself, the 1940s set a benchmark in its contribution to a safer, more orderly world. This project brought together existing legal concepts that stretched back as far as the 1215 Magna Carta, which proscribed arbitrary imprisonment and prescribed access to fair courts of justice and the liberty of the subject (habeas corpus). The pre-existing elements also included international humanitarian law to be applied in wartime, such as the Hague Conventions that emerged from 1899.

In the years following the late 1940s, under UN auspices, new conventions and treaties kept up this momentum towards an international rule of law focused on universal human rights. "Universal" meant what it said: no individuals fell outside their ambit, and the rights themselves constrained the actions of states even beyond their sovereign territories. ${ }^{11}$ The new provisions included the four Geneva Conventions of 1949, the International Convention on Civil and Political Rights (in force from 1976), the 1977 Geneva Protocol I, and the 1984 Convention against Torture. The elements of the new international rule of law spelled out the special rights of women, children, prisoners of war, refugees, and people with disabilities, as well as criminalising tor-

\footnotetext{
8 The text of the seven Nuremberg principles appears at http://deoxy.org/wc/wc-nurem.htm.

9 Mary Ann Glendon, A World Made New: Eleanor Roosevelt and the Universal Declaration of Human Rights (New York: Random House, 2001).

10 Sands, Lawless World, 152.

11 Ibid., Lawless World, 150-53.
} 
ture $^{12}$ The strengthening of this overall international legal framework seemed (and still seems) to offer the best hope of suppressing genocide.

From this vantage point, the US's subsequent relentless subversion of its own civilising project, the international rule of law, appears all the more startling. From 1949, American foreign relations began accelerating in the opposite direction, as if the Nuremberg trials, their jurisprudential achievements and later ramifications, had never seen the light of day (least of all in the Pentagon itself, where the Nuremberg principles were generated). I will have more to say on this about-face in the second section of this essay.

Having been the first country to sign the Genocide Convention, it took the US 40 years to ratify it. Even then it hedged its ratification with so many "RUDs" (reservations, understandings and declarations) that even the UK-along with 21 other Western countries-formally opposed them. ${ }^{13}$ The RUDs rendered the Convention a dead letter in American law and policy formation from the start. But as we shall see, US abhorrence towards genocide was strictly rhetorical up to ratification, and remained so afterwards, with no echo in the practice of American foreign relations. Of the 18 subsequent international human rights conventions and protocols, the US has ratified or acceded to just five. ${ }^{14}$

The successful resistance from within the US to the accumulating international human rights provisions (including the Genocide Convention) has rested on a vociferous defence of national sovereignty, which its own Nuremberg legacy had subordinated to the international rule of law. As we shall see, the thrust of US foreign policy during and after the Cold War has been to assert US sovereignty at the expense of the international rule of law and the national sovereignty of other countries. It is the only Western country to spurn the International Criminal Court (ICC - the successor to the International Military Tribunal in Nuremberg in 1945-1946). In its first years, the GW Bush Administration vilified the ICC, even legislated to criminalise co-operation with the court's investigations, and empowered the President to take military action against the court if any US official is ever brought before it. ${ }^{15}$

12 Ibid., 146-53. Sands summarises the historical development of the relevant international law. As he points out on page 152, the Fifth Amendment (guaranteeing due process) to the US Constitution provided key terms in which the new rights were expressed, starting with articles 10 and 11 of the UDHR.

13 Power, “A Problem,” 163-69. Denmark, Estonia, Finland, Greece, Ireland, Italy, Mexico, the Netherlands, Norway, Spain and Sweden also lodged formal objections to the RUDs attached to the US ratification.

14 Office of the UN High Commissioner for Human Rights at http://indicators.ohchr.org. For instance, the US is the only member of the UN that has not ratified or acceded to the Convention on the Rights of the Child (in force since 1990).

15 The American Service-members' Protection Act, 2002, informally known as "The Hague Invasion Act." See Sands, Lawless World, 62-63; Tatz and Higgins, The Magnitude, 187. Power, “A Problem,” 491, gives pro- 
American policy-makers' nonchalance towards what came to be known as genocide goes back a century, to 1915 when the Armenian Genocide began. The US Ambassador to the Ottoman Empire, Henry Morgenthau, kept his government well informed of the genocide's progress, yet the US refused to sign the joint British, French and Russian protest of May 1915 against "these crimes against humanity and civilisation." Under the doctrine of national sovereignty, US policy-makers reasoned, the Turks' slaughter of their own Armenian compatriots was no concern of other states, not least ones like the US that enjoyed good trading relations with the perpetrator state.

"America's nonresponse to the Turkish horrors established patterns that would be repeated," Power writes. "Time and again the U.S. government would be reluctant to cast aside its neutrality and formally denounce a fellow state for its atrocities." 16 Thus US backsliding from the 1950s constituted a return to the status quo ante (although, as we will see in the next section, there was more to it than that). However, the standard excuses did not apply during the Holocaust, when the US and Britain failed, in spite of vociferous lobbying, to bomb the death factory in Auschwitz- Birkenau and the railway leading thereto. ${ }^{17}$

Samantha Power presents us with the history of a protracted nonevent-the US's and its allies' failure ever to "put boots on the ground" to stymie highly publicised and enormously destructive genocides in the second half of the twentieth century. Two of them-targeting non-Serbs in the former Yugoslavia, and Tutsis in Rwanda_occurred after the Cold War ended, when the US was the world's sole superpower facing no appreciable threats elsewhere. The bystander policy persisted despite the fact that the Indian army (in East Pakistan in 1971), the Vietnamese army (in Cambodia in 1979), and a Tutsi rebel militia, the Rwanda Patriotic Front (in 1994), had demonstrated how limited military action can stop major genocidaires in their tracks. ${ }^{18}$

US inertia is all the more astonishing when we consider the enormous relative size of the country's military establishment, which it has maintained since the Cold War began. Today America's military spending accounts for 39 per cent of global military expenditure. At 596 billion USD, annual US military expenditure exceeds the aggregated military expenditure of the seven next-largest military powers. Its armed forces (excluding reservists and the

\footnotetext{
tectiveness of national sovereignty as the reason for US refusal to join the ICC, but given the circumstances reviewed in the second part of this essay, a far stronger motive is the one that the 2002 Act indicates: (wellgrounded) fear of US officials being indicted for gross infringements of international criminal law.

16 Power, “A Problem,” 13.

17 Tatz and Higgins, The Magnitude, 147-49.

18 Ibid., 100-02; Power, “A Problem,” 141.
} 
"civilian” CIA) comprise over 1.3 million personnel, 666 overseas bases (just part of its 103,270 overseas "assets" that encircle the world). ${ }^{19}$ Yet during the 1994 Rwandan genocide, this colossus even turned down a desperate request to use its technical capability to jam Radio Mille Collines, which was the main means used to incite and co-ordinate the genocide. US policy-makers saw this request as involving an unwarranted diversion of American resources. ${ }^{20}$

The Indian, Vietnamese and domestic Rwandan military actions remain our only post-war examples of troop deployments to stop genocide, apart from token UN peacekeeping missions. These aside, NATO (including US) bombers targeted genocidal Bosnian Serb forces for three weeks in 1995, long after their predicted and widely publicised atrocities in Srebrenica and other designated UN safe havens. NATO bombers raided Serbia itself, as well as its forces in Kosovo in 1999, when that country resumed genocidal attacks, this time against ethnic Albanians in the province in question. ${ }^{21}$ These aerial campaigns exhaust the American alliance's record of anti-genocidal military actions, and were not complemented by troop deployments.

As noted above, bystanderism is a powerful—and indeed indispensable - form of collusion in genocide, one that emboldens actual and potential genocidaires. Their ilk has learned from experience in virtually all cases that they have nothing to fear from the American alliance, whatever the identity and party affiliation of the sitting US president.

But American collusion has sometimes tipped over into active support for genocidal regimes. In 1979-1980 the US government continued to provide the genocidal Khmer Rouge regime with diplomatic legitimation in the UN, long after its atrocities had become common knowledge, and even after the Vietnamese had ousted it from Cambodia itself. (Quite apart from the issue of arch-criminality, under longstanding international law a regime should not receive diplomatic recognition if it no longer controls the country it claims to represent.) In the 1980s the American government strenuously defended Saddam Hussein's regime in Iraq, armed it, and provided it with substantial economic credits, at the same time as the latter was gassing and massacring its Kurdish population (as well as using gas and chemical weapons against Iranian troops in the Iran-Iraq war). ${ }^{22}$

19 Figures taken from the Peter G. Peterson Foundation, and the US Defence Department's most recently available Base Structure Report for fiscal year 2012, 7-8. These figures probably grossly underestimate actual overseas US bases and assets, as they do not, for instance, include the CIA's secret establishments: see Johnson, Nemesis, 137. He found 737 US bases on foreign soil in 2006.

20 Power, “A Problem,” 371-72.

21 Ibid., 440, 448.

22 Ibid., 146-54, 171-243. 
The American media had access to written and photographic evidence of all the genocides mentioned above in real time, and the progressive outlets at least did not stint in airing it. Commentators and op-ed writers often excoriated the US government for its collusion in genocide. For instance, during the US no-show while genocide was raging in Bosnia, Leon Wieselter wrote in The New Republic:

The United States seems to be taking a sabbatical from historical seriousness, blinding itself to genocide and its consequences, fleeing the moral and practical imperatives of its own power. . . . The American president is an accomplice to genocide. . . . The president of the United States does not have the right to make the people of the United States seem as indecent as he is. He has the power, but he does not have the right. ${ }^{23}$

In light of such spirited criticism from at least part of the American fourth estate, we have to ask how the US government has retained legitimacy in the absence of decency.

In answer to this question we can briefly extrapolate five governmental ploys from Power's account. The first one-best illustrated by the government's non-response to the Cambodian, Iraqi and Rwandan genocides-is to simply ignore the genocide. Not acknowledge it, not summon meetings of senior advisors, not find any place for it on the policy agenda. The second ploy is to trivialise the genocide, or present it as intractable, or both. When the first ploy began to fail in the Rwandan case, and again in the Bosnian one, this second one came into its own. US officials deplored mass death as a "tragedy" due to "war" that arose out of "ancient tribal hatreds"; it was a question of perennial internecine strife that no third force could possibly ameliorate, let alone end. Perpetrators and victims were equally to blame.

The third ploy consists in discounting the evidence. The relevant genocides all commanded widespread media coverage, while the US government had its own lavish sources of intelligence, including (since the 1980s) high-resolution satellite imagery. Yet officials described all reports of genocide as "unconfirmed," or "lacking specific detail," and thus insufficient to trigger intervention. The fourth ploy is the populist self-referential argument that a genocide does not threaten America’s “vital interests," so no such interest is served by initiatives to stop genocide.

But the fifth, most practised ploy has been to forbid US officials' use of the word "genocide” itself—-the dreaded "g-word.” In extremis, officials could 
use weasel formulations such as "acts of genocide" and "tantamount to genocide," all of which fall short of plain genocide, with all the moral and legal imperatives it would attract. Power notes that some junior officials chafed at these shabby word games, hence the State Department maintained an internal "dissent channel" through which they could vent their frustration into the silence of the upper echelons without jeopardising their careers. In 1999 that department endured its third "g-word" controversy in six years, and for the first time it authorised the "tentative use" of the g-word 10 days before NATO began bombing the Serbs. At the same time, in a first for the US presidency, Bill Clinton referred to "deliberate, systematic efforts at genocide." 24

Samantha Power comes to the counterintuitive-but ineluctable-conclusion that US policy towards genocide has hardly proved a failure:

Simply put, American leaders did not act because they did not want to. ... One of the most important conclusions I have reached, therefore, is that the U.S. record is not one of failure. It is one of success. Troubling though it is to acknowledge, U.S. officials worked the system, and the system worked. ${ }^{25}$

This insight brings more questions into view. What purpose does this perennial collusive policy serve? What other reasons of state (raisons d'état) does it make room for? Is "the system" that Power refers to just institutionalised moral nihilism, or is it a sub-assembly in a more encompassing system? What is the US's gargantuan military establishment for (given that genocide prevention clearly lies outside its remit)? Under what conditions could the political will to prevent and punish genocide arise-thus reversing the current longstanding bystander policy?

To answer these questions we have to go beyond the narrow disciplinary confines of genocide studies, to consider the rationale of America's post-war relationship to the wider world, and the actual (as opposed to rhetorical) nature of its political culture and system.

\section{Empire versus law and democracy}

America's inertia in the face of genocide stands in stark contrast to its habit of intervening — frequently, brutally, and uninvited—in the affairs of many other

24 Power, “A Problem,” 467-68. Quote on 468, emphasis added.

25

Ibid., 508. 
countries in pursuit of its "vital interests." In the wider context of American foreign relations, these extremes - of inertia on the one hand, and multiple trespass on the other-constitute the two sides of the same imperial coin. As against the US's near-zero score for military operations to stop an ongoing genocide, between the end of World War Two and 9/11 in 2001 it mounted over 200 overseas military incursions - typically unprovoked, ${ }^{26}$ usually from one or several of its hundreds of overseas military bases noted above. And since 9/11, the American alliance has invaded Afghanistan and Iraq, sparking still-ongoing wars, massive humanitarian crises, and genocidal risks that have drawn in several neighbouring countries, either as unwilling battlefields or willing participants. Thus, traditional US isolationism certainly does not explain that country's absence from the struggle against genocide.

In our recent book, The Magnitude of Genocide, Colin Tatz and I dedicate a chapter to pondering Steven Pinker's thesis that violence (including war and genocide) has tended to decline over the last five millennia, and that the decline in question has steepened in the modern era. Pinker plausibly considers the factors that have contributed to this trend, including democracy. ${ }^{27}$ "The idea of democracy, once loosed upon the world, would turn out to be one of the greatest violence-reduction technologies since the appearance of government itself," he writes. ${ }^{28}$ War has profound negative impacts on political communities that, if empowered through genuinely democratic representation, inhibit warmongering. Most if not all democratic polities recoil from genocide.

The core members of the American alliance conventionally pass for fullyfledged democracies, yet they demonstrably have no interest in meeting their moral, legal and treaty obligations to curb genocide. At the same time, they have repeatedly initiated war and disturbed the peace in other countries-in flagrant contravention of post- Nuremberg international criminal law-thus sowing the seeds of future genocides. If we assume for the sake of argument that Pinker's general claim for democracy holds water, we must now look more critically into the democratic credentials of the American alliance. I will turn to the travails of American democracy below, and to those of Western countries in general in the next section.

Self-evidently American democracy rests on its 1787 Constitution-the inspired work of framers steeped in Enlightenment thought (especially Montesquieu's), the history and constitution of the Roman Republic (509-27

26 Johnson, Nemesis, 2007, 18; Johnson, Dismantling the Empire, 56. And see the list of US military incursions at http://academic.evergreen.edu/g/grossmaz/interventions.html.

27 Tatz and Higgins, The Magnitude, 191-225; Pinker, The Better Angels, 2011.

28 Ibid., 194. 
BCE), and the development of English common law with its reigning concept of the rule of law. The venerable civic-republican tradition united the Constitution's framers on the side of freedom understood as popular self-rule, as against tyranny understood as the capricious, hubristic rule of one individual or a closed cabal. The framers adopted Montesquieu's schema of the separation of powers-legislative executive, and judicial, in that order - to provide the checks and balances to prevent tyranny. The legislature in which "we the people" were represented was to take pride of place.

Acutely aware as the framers were of the historic link between tyranny and warmongering, they vested the power to declare war exclusively in the legislature. "Of all the enemies of true liberty, war is, perhaps, the most to be dreaded, because it comprises and develops the germ of every other," declared James Madison (sometimes dubbed "the Father of the Constitution") in $1795 .{ }^{29}$ The framers insisted that all expenditure of public funds be publicly accounted for, as just one aspect of every citizen's essential right to know what public officials are doing, how and why. Without that knowledge, the public cannot make informed decisions and exercise popular sovereignty over those in positions of power. The framers bolstered the rule of law by insisting that treaties, once duly entered into, constitute part of the law of the land. The fourth amendment to the Constitution protects citizens' privacy from "unreasonable" searches and seizures by agents of the government, while the fifth guarantees due process.

At this point Chalmers Johnson's analysis becomes relevant. Apart from his long career as a prominent American political analyst, he served as a naval officer during the Korean War, and as a consultant to the CIA between 1967 and 1973. He identified with the US republican tradition and its constitutional basis, but entertained dire fears for American democracy and constitutional observance in the post-war era, not least since 9/11. I will briefly extrapolate the main arguments from his four relevant books. ${ }^{30}$

In the post-war period four factors have driven the US to develop its "empire of bases," the present colossal extent of which is sketched above. The first factor was "military Keynesianism"- the maintenance of high levels of military spending to stimulate manufacturing, general economic activity, and employment in the domestic economy. ${ }^{31}$ The second factor was Cold War rivalry with the Soviet Union. Clearly, these two factors have reinforced each

\footnotetext{
29 Quoted in Johnson, Nemesis, 18. This sentiment foreshadows Pinker's thesis (mentioned above) that democratic governance constitutes an anti-violence "technology."

30 See note 4. Of these, the third book is perhaps the most comprehensive.

31 Johnson, Nemesis, 271-78.
} 
other. The third factor was US dependence on imported oil, not least from the Middle East. Together these factors drove US military self-projection onto the world stage. They led to the hundreds of military incursions into foreign countries mentioned above, many of which were clandestine and kept secret from the American public —at least until well after the event.

This pattern led to a fourth, fateful imperial dynamic: "blowback." The CIA coined this term as a contribution to its own tradecraft in 1953, after one of its early staged coups against a democratic but inconvenient foreign government, that of Iran. The term arose from the insight that such gross trespass in the affairs of other countries could visit negative consequences on the US itself. Johnson elaborates the concept to extend it to its effects on US domestic politics. When the blowback comes, the American public is not able to put it into context, given the clandestine nature of the original American provocation, which it knows nothing about. Blowback-attacks on US military assets, embassies and citizens overseas, and eventually on the US itself on 9/11 - thus appears to the American public as gratuitous aggression. It fuels popular mobilisation around hefty US retaliation, culminating in the invasions of Afghanistan and Iraq in 2001 and 2003 respectively, and the heady warlike mood at home. ${ }^{32}$ Seen in this light, blowback is not simply a question of oneoff events, but a vicious circle that puts the US and its core allies on a more or less permanent war footing against a growing list of sworn enemies. The President's role as the executive of a constitutional democracy gives way to his status as Commander-in-Chief of the armed forces in (real or rhetorical) wartime-a commander in whose office the twin phenomena of empire and militarism converge.

James Madison's "dread" of war as a threat to the republican order was thus prophetic. In the latter half of the twentieth century and in the current one, a republican presidency has morphed into an "imperial presidency" that comprehensively denies the citizens' right to information, and overrules the legislature, the rule of law, and the judiciary. ${ }^{33}$ All the features of the Constitution mentioned above have been effectively curtailed, its checks and balances now little more than ritualistic relics. Government has sunk ever more deeply into illegality, such as holding prisoners indefinitely without trial

\footnotetext{
32 Johnson, Nemesis, 278.

33 The US presidency has developed the practice — energetically deployed by GW Bush—of issuing "signing statements" when signing congressional bills into law. In these documents, the President purports to suspend or modify the effect of the bill. This mechanism means that he can frustrate the legislature's intent without issuing a formal veto, which could in turn be overruled by a two-thirds majority in Congress: Johnson, Nemesis, 248, 257-60. The practice quashes the fundamental point in the Constitution (Article 1), that Congress shall have exclusive power over legislation.
} 
under grotesquely inhumane conditions; routine, officially sanctioned kidnapping and torture; and spying on the American citizenry-again flouting the Constitution, treaties duly entered into, and domestic law. ${ }^{34}$

The main cause (as well as effect and beneficiary) of this fall from legal and democratic grace has been the CIA itself. It began life in 1947, as a replacement for the Office of Strategic Services, which had played a progressive role, for instance, in servicing the American prosecution in the first Nuremberg trial of 1945-1946. In contrast, the CIA has been set up to serve the President only, by supplying intelligence and assessments of threats to US security, and undertaking subsidiary "operations." It soon became (in Johnson's term) the President's secret private army, as its "operational" functions overtook its intelligence-gathering ones. ${ }^{35}$ No president has been able to resist using it as a private army. In the year of its establishment it interfered in Italian politics. Two years later it toppled the democratic government of Syria (destroying that ill-fated country's first and arguably last chance of attaining stable, peaceful democratic government) in order to advance the interests of the Arabian American Oil Company (Aramco). ${ }^{36}$

The CIA's orientation and main modus operandi were now set. It has directly or indirectly unseated a long list of democratic governments, replacing them with brutal despotisms, among other places in Iran (as noted), Guatemala (1954), Indonesia (1957-1958), Brazil and South Korea (both in 1961), Greece (1964), Ghana (1966), the Philippines (on multiple occasions), and Chile (1973). The CIA's obsession with regime change has rubbed off onto senior US policy-makers in general: it was the main motive behind the invasion of Iraq in 2003. The agency mounted the abortive 1961 invasion of the Bay of Pigs in Cuba, and made several attempts to assassinate Fidel Castro. Its secretiveness confers unaccountability and "plausible deniability" for all its transgressions on its one and only client-the US President. ${ }^{37}$ As Johnson comments:

The CIA remains the main executive-branch department in charge of over-

\footnotetext{
34 Johnson, Nemesis, 204-05, 254-45, 258-89. See also US Senate Select Committee on Intelligence, Committee Study of the Central Intelligence Agency's Detention and Interrogation Program: Findings, Conclusions and Executive Summary (Washington: US Senate, 2014); Sands, Lawless World, 205-23; Michael Hayden, Playing to the Edge: American Intelligence in the Age of Terror (New York: Penguin, 2016).

35 Johnson, Nemesis, 92-93.

36 Charles Glass, Syria Burning: A Short History of a Catastrophe, 2nd ed. (London: Verso, 2016), 20-23.

37 The authoritative history of the CIA is Tim Weiner, Legacy of Ashes: The History of the CIA (New York: Anchor Books, 2008) - the fruit of 20 years of research.
} 
throwing foreign governments, promoting regimes of state terrorism, kidnapping people of interest to the administration and sending them to friendly foreign countries to be tortured and/or killed, assassination and torture of prisoners in violation of international and domestic law, and numerous "wet" exercises that both the president and the country in which they are executed want to be able to deny. ${ }^{38}$

In direct contravention of the Constitution, its entire budget (14.7 billion USD in 2013) is kept secret from the public and immune to congressional oversight—along with about 40 per cent of the overall US military budget. ${ }^{39}$

Long before 9/11—and as the essential precondition thereto-the CIA (in league with its British counterpart, MI6) launched its most fateful operation, in Afghanistan in July 1979. It armed and encouraged jihadi extremists, the mujahideen, to revolt against the secular, modernising pro-Soviet government that sought, among other things, to provide girls with schooling, which the extremists abhorred. The CIA aimed to lure the Soviet Union to come to the Afghani government's aid, whereupon the Soviets would bog down in a counter-insurgency and so get their own "Vietnam."

The Soviet Union duly took the lure six months later, and the CIA and MI6 ramped up their aid to the mujahideen. The CIA's chief of station in Pakistan from May 1981, Howard Hart, took charge of clandestine operations in Afghanistan. As he himself paraphrased his superiors' orders, they were: “Here’s your bag of money, go raise hell. Don’t fuck it up, just go out there and kill Soviets, and take care of the Pakistanis and make them do whatever you need to make them do." ${ }^{41}$ Among the beneficiaries of the CIA's tutelage and largesse was a promising young Saudi fanatic called Osama bin Laden: the CIA built him and his followers (al Qaeda) a base in Khost province in eastern Afghanistan. ${ }^{42}$

The sequel is well known: the Soviet Union suffered 15,000 war dead, and withdrew from Afghanistan in 1989, only to collapse in 1991. Mission accomplished, then. In the process, 1.8 million Afghanis were killed in the CIA-staged civil war, and 2.6 million became refugees. One jihadi element,

\footnotetext{
38 Johnson, Nemesis, 102.

39 We only know the size of the CIA budget thanks to the leaker Edward Snowden and the Washington Post. The US fields 16 intelligence services, which share 52.6 billion USD between them: http://www.bbc.com/news/worldus-canada-23903310. See also Johnson, Nemesis, 9.

40 Johnson, Nemesis, 110-11.

41 Steve Coll, Ghost Wars: The Secret History of the CIA, Afghanistan, and Bin Laden, From the Soviet Invasion to September 10, 2001 (New York: Penguin, 2004), 33-35. Quote (from interviews with Hart) on 35.

42 Coll, Ghost Wars, 156-57.
} 
the Taliban, seized control of Kabul in 1996, while another, al Qaeda, turned its attention (and CIA-sourced skills and weaponry) on the US itself. ${ }^{43}$ Such is the backstory to 9/11 and today's ongoing wars in Afghanistan and Iraq.

Presidential fury and hubris after 9/11 unleashed the CIA from the few legal and moral restraints on it. As Commander-in-Chief in "wartime"-so designated by his "war on terror" slogan—President Bush claimed exemption from legal and constitutional compliance. As Philippe Sands argues, the administration's "war on terror" implied a "war on law"; it made "a conscious decision . .. to propel its assault on global rules." 44 Tyranny breeds lawlessness at home, too. ${ }^{45}$ Kidnap and torture, which had hitherto been a small and furtive part of the CIA's operations, now became a major part of it, with the President's written approval. The US is a party to the 1984 UN Convention against Torture that (under the US Constitution) makes it part of the law of the land, so this entire programme was felonious even in American domestic law.

Nonetheless, the CIA began kidnapping large numbers of people from North America, Western Europe and the Middle East, and sending them to torture-friendly allied countries (Egypt and Syria in the main), and to its own "black sites" around the world, including its larger facilities such as Abu Ghraib, Bagram air base, and Guantánamo Bay. Bush declared the victims to be "bad people" and "unlawful combatants" to whom no legal protections whatever applied. They occupied (in Sands' term) a "legal black hole" that negated all applicable legal developments from Magna Carta to the present day. ${ }^{46}$ Photographic, video and written accounts of the sadistic practices inflicted in this black hole flooded the world media. In all the facilities mentioned, the CIA oversaw the torturing of its captives to extract "intelligence." 47 (In a rare moment of self-assertion, the US Senate inquired into this "extraordinary rendition program" and found it to have been ill-conceived, poorly managed, and fruitless. But the public is still not allowed to see the Inquiry's full report, only a comparatively short summary. $)^{48}$

43 Coll relates in 588-page detail the history of the US-led imbroglio in Afghanistan, and lays bare the CIA's brutality and incompetence therein.

44 Sands, Lawless World, xii, 153.

45 See Naomi Wolf, The End of America: Letter of Warning to a Young Patriot (Burlington, VT: Chelsea Green Publishing, 2007).

46 Sands, Lawless World, 143-73.

47 See Philippe Sands, Torture Team: Deception, Cruelty and the Compromise of Law (London: Penguin, 2008).

48 Two NATO members-Italy in 2005 and Germany in 2007-issued arrest warrants and extradition requests for 22 and 13 CIA agents respectively, for involvement in kidnap-and-torture operations within their jurisdictions: Johnson, Nemesis, 131-15; Matthias Gebauer, “Germany Issues Arrest Warrants for 13 CIA Agents in El-Masri Case,” Der Spiegel, January 31, 2007, http://www.spiegel.de/international/el-masri-kidnappingcase-germany-issues-arrest-warrants-for-13-cia-agents-in-el-masri-case-a-463385.html. Readers with a taste for 
The framers of the 1787 US Constitution would have recognised this pattern of constitutional, legal and democratic eclipse. They were acutely aware of the fate that overtook the Roman Republic that they so greatly admired. Having over-committed to territorial expansion and the militarism it entailed, the Republic signed its own death warrant by appointing Julius Caesar, a populist military hero, dictator for the years 49-44 BCE, and then dictator for life. The stage was then set for the long-lived imperial absolutism first exercised by Caesar's grandnephew, Augustus. This return to tyranny was precisely the fate that the framers sought to spare their new American republic. "The collapse of the Roman Republic offers a perfect case study of how imperialism and militarism can undermine even the best defenses of a democracy," Johnson comments. ${ }^{49}$

Just as the Caesars enjoyed pseudo-legal backing for their despotism, so too the US imperial presidency found support in a neoconservative contribution to jurisprudence called "the unitary executive theory of the presidency.” Among other things, it asserts the President's supremacy in all matter relating even indirectly to foreign relations and war, thus overriding all existing laws (including on due process and torture) that might otherwise have countermanded his executive orders. ${ }^{50}$ Resort to the doctrine violates the Constitution's central principle-the sovereignty of "we the people" as exercised by elected lawmaking representatives in congress. This neocon principle chimes with the Nazi jurisprudence based on the Führerprinzip (leadership principle), which declares it impossible for the Führer to break any law because his will is the law. The doctrine formed part of the neocons' mission to create a whole "new legal regime," ${ }^{51}$ one based on a single, simple principle: force majeure. It compromises the integrity of the whole international rule of law on which the struggle against genocide depends.

gallows humour can visit the CIA's statement of its "vision, mission, ethos, and challenges" on its official website. Under the rubric "Integrity" it reads: "We uphold the highest standards of lawful conduct. . . . We maintain the Nation's trust through accountability and oversight.” This claim competes with Heinrich Himmler's constant insistence on the Anständigkeit (decency) of his SS mass-murderers: see Yitzhak Arad, Yisrael Gutman and Abraham Margoliot, eds., Documents of the Holocaust: Selected Sources on the Destruction of the Jews of Germany and Austria, Poland and the Soviet Union (Jerusalem: Yad Vashem, with the Anti-Defamation League and Ktav Publishing House, 1981), 344.

49 Johnson, Nemesis, 55.

50 Johnson, Nemesis, 253. As he relates, Bush appointed two proponents of the new jurisprudence to the bench of the US Supreme Court in 2006. Much earlier, another justice thereof, Robert Jackson-the legendary US chief prosecutor in the first Nuremberg trial—delivered a judgment in 1952 that explicitly denied that the President had any special powers in wartime; even then his power "is subject to limitations consistent with a constitutional Republic whose law and policy-making branch is a representative Congress.”

51 John Yoo, US Deputy Assistant Attorney General, announced this as the Bush Administration's intention in 2002. See Sands, Lawless World, 153-34. "We're an empire now, and when we act, we create our own reality,” Yoo’s fellow neocon, Karl Rove, famously asserted. See Richard Flanagan, “Does Writing Matter?” The Monthly, October (2016), 23. The "new legal regime" took its place in that created reality. 
Johnson insists — and this is his central point - that democracy and the rule of law on the one hand, and imperialism on the other, are irreconcilable, because the maintenance of empire abroad in the long run demands tyranny at home. One or the other must give way. In Rome it was democracy and law that foundered. Following Hannah Arendt in The Origins of Totalitarianism, Johnson cites a counter-example- the British Empire. In this case the empire was dismantled (albeit often with the robust encouragement of the colonised) to eradicate its threat to the democratic and law-bound order at home. ${ }^{52}$ On this argument, the US must choose between the "Roman" and "British" options. ${ }^{53}$

If the US continues down the present "Roman" path, Johnson wrote, it faces "a devastating trio of consequences: imperial overstretch, perpetual war, and insolvency, leading to a likely collapse similar to that of the Soviet Union." 54 At the time of writing, the US national debt (duly engorged by the lavish military budget) comes to 19.34 trillion USD, or 106 per cent of GDP. ${ }^{55}$ The Last Days of the American Republic - the sub-title of Johnson's Nemesis-thus refers not just to the country's democratic and constitutional implosion, ${ }^{56}$ but also to its current fiscal frailty as a nation-state.

If the US were to choose the "British" path, it would dismantle its empire of bases, starting with the abolition of the CIA, ${ }^{57}$ and then be in a position to return to its American first principles-restore its constitutional, democratic and legal order. It might then resume the path it was treading in the 1940s when it was promoting an international rule of law, one antithetical to aggressive war and genocide, among other humanitarian violations. Unfortunately, few signs point to such a return. Obama's presidency saw the US faltering in its slide into tyranny, but not going into reverse. It did not distance itself from the criminality and lawlessness of its predecessor, let alone apologise or offer restitution to those wronged. The wars in Afghanistan and Iraq continue, and have metastasised into Libya, Syria and Yemen. The CIA endures, as does its "extraordinary rendition" programme, as does the Guantánamo hellhole ${ }^{58}$-all powerful symbols of the "Roman" path, and perhaps harbingers of the "Soviet" fate. In the next section I will disclose more sources of resistance

\footnotetext{
52 Johnson, Nemesis, 88.

53 Johnson, Dismantling the Empire, 29.

54 Ibid., 183. Oddly, he fails to cite the case of the French First Republic (1792-1804) that morphed into the ill-fated (Napoleonic) First Empire.

55 http://www.usdebtclock.org/.

56 In this context, see Naomi Wolf, The End.

57 Johnson, Dismantling the Empire, 28, 82.

58 Jonathan Hafetz, ed., Obama's Guantánamo: Stories from an Enduring Prison (New York: New York University Press, 2016).
} 
to a democratic revival, ones not specific (but still applicable) to the American case.

Before I turn to them, I will raise one more connection between the imperialism/militarism couple and collusion in genocide. As Colin Tatz and I have argued, today's genocidal threats are largely concentrated in the Middle East and North Africa. Most of them take the form of ISIS, its allies, and its fervid jihadi imitators. US-led aggression and subsequent military bungling from July 1979, and especially in the wake of 9/11, let this "horde of genies" out of their bottles and have provided them with four major failed states (Afghanistan, Iraq, Syria and Yemen) in which to spread genocidal mayhem. ${ }^{59}$ When we connect the causal dots, we lay bare the link between hubristic and impulsive decision-making - the hallmarks of tyranny-in the US on the one hand, and potentiating genocide elsewhere on the other. This link represents the converse of Pinker's thesis about democracy's efficacy as a violence dampener, and points up the third aspect of the American alliance's collusion in genocide mentioned in my introduction.

\section{Post-democracy, bread and circuses}

How might Western powers thwart today's principal genocidal threats in the Middle Eastern cauldron-ones that core members of the American alliance have conjured forth since 1979, and especially since 9/11? The military and intelligence specialist David Kilcullen concludes his analysis of the problems and options here on a challenging note: the central resource we need to tap into in this struggle is political will:

This_-political will, not troops, not money, not time, not technology — this is the scarcest resource, and without that political will at the level of entire nations, nothing else we do will work. Preserving and strengthening the political will of our societies, the will to continue this struggle without giving

59 Tatz and Higgins, The Magnitude, 227-41. "Horde of genies” is David Kilcullen’s expression; we made extensive use of his shrewd analysis in our discussion. Inter alia, he reinforces the general view that the 2003 invasion of Iraq was not only illegal, but a catastrophic misstep: "the greatest strategic screw-up since Hitler's invasion of Russia.” See David Kilcullen, "Blood Year: Terror and the Islamic State,” Quarterly Essay 58 (2015), 11. The UK government's Iraq inquiry, headed by Sir John Chilcot, reported in July 2016 and came to much the same conclusion. It spells out the deceit, chicanery and recklessness that underpinned the British decision to join in the US-led invasion. But even this report pulled its punches on key points, such as on the sheer illegality of the invasion: see Philippe Sands, “A Grand and Disastrous Deceit,” London Review of Books 38, no. 15 (2016), 9-11. Australia's more denialist political culture will probably preclude any such independent inquiry into its own government's decision to join in the 2003 invasion; were such an inquiry to come to pass, however, its findings would probably replicate Chilcot's. 
in to a horrific adversary, but also without surrendering our civil liberties or betraying our ethics, is not an adjunct to the strategy-it is the strategy. ${ }^{60}$

As he makes clear, this struggle will be long and gruelling. By "political will," then, he does not mean fleeting popular assent to something like the catastrophic 2003 invasion of Iraq, which then US Defence Secretary Donald Rumsfeld sold to the public as a sure-fire quick-fix "cakewalk" (now a war in its fourteenth year). Rather, the "political will at the level of entire nations" needed to bring today's genocidaires to ground has to replicate the sustained, encompassing kind that galvanised the Allied home fronts during World War Two, even if the present conflict itself is not on that scale. Only substantive democratic processes can engender such durable mobilisation, as they did then.

In addition to the obstacles already canvassed-the ongoing, genocidecollusive thrust of the American alliance's foreign relations since 1949, and the corrosion of constitutional government and the rule of law in the US itself-several writers point to other travails of democratic governance in today's West that militate against the formation of a durable democratic will of the kind required. I will briefly introduce one influential strand in this literature, again focusing on the work of its main proponent.

In his book Post-Democracy, Colin Crouch sets up two ideal types of formally democratic government over the past century. The first, "democracy" as such,

thrives when there are major opportunities for the mass of ordinary people actively to participate, through discussion and autonomous organizations, in shaping the agenda of public life, and when they are actively using these opportunities. ${ }^{61}$

In the core countries of today's American alliance, democracy's high tide arrived in the mid-twentieth century, ${ }^{62}$ and they came at least a fair way to achieving this ideal.

A half-century later, though, a new model-post-democracy-has supplanted it:

Under this model, while elections certainly exist and can change governments, public electoral debate is a tightly controlled spectacle, managed

60 Kilcullen, "Blood Year," 87. Emphasis added in the first two italicised phrases.

61 Crouch, Post-Democracy, 2.

62 Ibid., 7. 
by rival teams of professional experts in the techniques of persuasion, and considering a small range of issues selected by those teams. The mass of citizens plays a passive, quiescent, even apathetic part, responding only to the signals given them. Behind this spectacle of the electoral game, politics is really shaped by private interaction between elected governments and elites that overwhelmingly represent business interests. ${ }^{63}$

The trend towards post-democracy gained its impetus from the overlapping Reagan and Thatcher years in the 1970s, when progressive politics in the West foundered in the oil crisis and concomitant stagflation. Neoliberal ideology then began its rapid rise to ascendancy, Crouch argues, to the point where Margaret Thatcher could notoriously claim, "there is no alternative." There has certainly been no alternative to neoliberalism in the mainstream electoral lives of the American alliance's core members since at least the 1980s, hence the narrow compass and impoverishment of political contestation to this day.

Post-democracy, far from mobilising and crystallising the political will of "we the people," empowers a new political class made up of corporate elites (including media moguls), professional lobbyists, and politicians' career staffers, minders, spin-doctors, brand- and image-controllers, perception-managers, and focus-group ringmasters-all united around neoliberal nostrums. In this scenario, Crouch writes, citizens "have been reduced to the role of manipulated, passive, rare participants," while "the content of party programmes and the character of party rivalry become ever more bland and vapid." ${ }^{4}$ The closer the core members of the American alliance gravitate towards this model of political life, the more remote becomes the prospect of generating an antigenocidal "political will at the level of entire nations."

Indeed, "we the people" find ourselves denied access to our supposed representatives - shouldered aside by corporate donors and professional lobbyists representing well-heeled clients under the terms of the cash-for-access system. "We the people" also experience increasing difficulty in finding the vocabulary and syntax with which to express any political will at all, given the current corruption of public language. Post-democracy imposes an idiom drawn from the professional manipulators of the advertising industry, and "advertising is not a form of rational dialogue," as Crouch drily observes. ${ }^{65}$ It coaches politicians and other members of the political class into uttering "sound bites"—or

63 Ibid., 4. On the role of (and benefits to) business interests in the alliance's military adventures, see Naomi Klein, The Shock Doctrine: The Rise of Disaster Capitalism (New York: Allen Lane, 2007).

64 Ibid., 21.

65 Ibid., 26. 
performing more drawn-out speech-acts - that do not resemble normal speech, but rather comprise Orwellian sequences of boiler-plate phrases, slogans, cant and weasel words that "articulate a vague and incoherent set of policies."66 This corruption of language, exemplified by today's “retail politicians," is another hallmark of the tyranny that betokens democracy's malaise.

In the absence of rational public dialogue, "we the people" are diverted into choreographed rituals, hoop-la, and political spectacles that offer a mere simulacrum of political participation (but supposedly display our countries' democratic credentials). In reality they are little more than "media events"-advertising platforms for self-selecting elements of the political class, and therewith festivals of sloganising, posturing and cant. ${ }^{67}$ All of this falls well short of Crouch's desiderata for democracy quoted above.

The American primaries in the run-up to the November 2016 presidential election made this point plainly enough: they constituted show business, not democratic conversations. ${ }^{68}$ The campaign itself also illustrated a related but even more hazardous side of post-democracy: its propensity to reduce large segments of the citizenry to blind resentment at their socio-economic exclusion and insecurity under neoliberal policy regimes, ${ }^{69}$ and their political exclusion at the hands of the political class. These segments can then fall in behind disreputable chancers who foment atavistic prejudices and entirely lack experience in public office. This scenario invites comparison with the fall of the German Weimar Republic in 1933 and its genocidal aftermath. We have certainly come a long way from the preconditions for an anti-genocidal political will at the level of whole nations.

Finally, the national governments and political elites of the American alliance rely on greater and greater secrecy to disempower their supposedly fully informed democratic constituencies_-something that James Madison also foresaw as aiding the "gradual and silent encroachments of those in power."70 Earlier I referred to the secrecy surrounding vital elements of Amer-

66 Ibid., 27. Much of this “cant, gibberish and jargon,” as Don Watson calls it, also comes from contemporary management argot. Watson's mockery of contemporary political language serves a serious point in showing how much is lost in "the decay of public language." See Don Watson, Death Sentence: The Decay of Public Language (Sydney: Knopf, 2003); Don Watson, Watson's Dictionary of Weasel Words: Contemporary Clichés, Cant and Management Jargon (Sydney: Vintage, 2005); Don Watson, Worst Words: A Compendium of Contemporary Cant, Gibberish and Jargon (Sydney: Vintage, 2015).

67 Daniel Dayan and Elihu Katz, Media Events: The Live Broadcasting of History (Cambridge MA: Harvard University Press, 1992); Maria Wendt, Politik som spektakel: Almedalen, mediemakten och den svenska demokratin (Stockholm: Atlas Akademi, 2012).

68 Eliot Weinberger, "It Was Everything,” London Review of Books 38, no. 16 (2016), 3-8; Christian Lorentzen, “Diary,” London Review of Books 38, no. 16 (2016), 4.

69 See Crouch, Post-Democracy.

70 Speech delivered on June 6, 1788, at the Virginia Convention to ratify the Federal Constitution. 
ican foreign relations, military excursions, and covert operations. In each of the core countries, applications for official documents made under freedomof-information legislation have long met with ever-stiffer resistance motivated by vague references to "national security" or "national interests.” When documents are released, they are often "redacted" to the point of deliberate unintelligibility. "Welcome to Peak Secrecy," the Australian journalist Sarah Gill comments-thus pinpointing another integral feature of post-democracy. ${ }^{71}$

\section{Conclusion}

Colin Tatz and I ended our recent book on genocide with this sentence: "The prevention of genocide is every citizen's business."72 To a large extent, the genocidal risks that the world faces today arise from the political dysfunctions and imperial overstretch of the US and its closest allies, and their catastrophic long-run outcomes in the Middle East and North Africa. Thus for the citizens of the core members of the American alliance, the business of preventing genocide begins at home.

It begins by challenging our political and policy-making elites — their longstanding, institutionalised moral indifference to genocide; their brazen assault on the international rule of law on which the struggle against genocide depends; their subversion of domestic law; their inured imperial mind-sets; and their debauching of democratic rule at home. The task of building a political will to prevent genocide at the level of whole nations demands nothing less than reinstating our Western democratic politico-legal heritage so limpidly expressed in the 1787 US Constitution, and implicit in the Constitutions of the UK and Australia. It also requires a retrieval of the political culture of the 1940s, when our countries were truly democratic, belonged in the mainstream of Western civilisation, and energetically sought to nurture an international rule of law that would suppress war and genocide, and promote human rights.

Can the American alliance stop colluding in genocide? We stand at a crossroads much like the one where the classical sociologist Max Weber located the "iron cage" of capitalist society over a century ago in The Protestant Ethic and the Spirit of Capitalism:

No one knows who will live in this cage in the future, or whether at the end

71 Sarah Gill, "We've Reached Peak Secrecy, In a New Low Point for Transparency and Openness," Sydney Morning Herald, October 27, 2016. A draconian case in point is s.42 of the 2015 Australian Border Force Act that threatens members of the caring professions with imprisonment for disclosing the conditions under which imprisoned asylum seekers suffer.

72 Tatz and Higgins, The Magnitude, 249. 
of this tremendous development entirely new prophets will arise, or there will be a great rebirth of old ideas and ideals, or, if neither, mechanized petrification, embellished with a sort of convulsive self-importance. ${ }^{73}$

We citizens of American-alliance countries face well-entrenched and well-resourced resistance to any attempt to recover our politico-legal patrimony in our own homelands. But the stakes could hardly be higher: not only our own civilisation and way of life, but also the lives of millions of potential genocide victims far beyond our national borders.

73 Max Weber, The Protestant Ethic and the Spirit of Capitalism, trans. Talcott Parsons (1905; London: Routledge, 1992), 124. 